Tomasz Graff

Uniwersytet Papieski Jana Paw£a II

\title{
Wokół staropolskich fundacji i benefaktorów Szkół Nowodworskich w Krakowie
}

Historia Szkół Nowodworskich od lat zajmuje badaczy. Największy wkład w odkrywanie staropolskich dziejów tej instytucji miał bez wątpienia Henryk Barycz. Od czasów publikacji w 1988 roku drugiego wydania jego Historii Szkót Nowodworskich. Od założenia do reformy $H$. Kołłątaja ${ }^{1}$ badania nad najstarszym okresem funkcjonowania słynnego krakowskiego Nowodworka właściwie jednak zamarły. Niewątpliwie cennym uzupełnieniem okazała się praca Marka Ferenca, który ostatnio omówił dzieje Collegium Nowodworskiego². Również autor tych słów kilka lat temu zajął się historią tej placówki w XVI-XVIII wieku. Nowe ustalenia tam zawarte dotyczące fundacji i benefaktorów zostały jednak tylko zasygnalizowane na szerszym tle przedstawionych rozważań ${ }^{3}$. Dlatego celowe wydało się powrócenie do tego tematu w osobnym artykule.

5 maja 1586 roku w trakcie rektoratu Piotra z Gorczyna ${ }^{4}$ na uroczystym zebraniu przełożonych wszystkich wydziałów oraz pozostałych nauczycieli postanowiono utworzyć bezpośrednio zależne od Akademii Krakowskiej scholae

${ }^{1}$ H. Barycz, Historia Szkół Nowodworskich. Od założenia do reformy H. Kołłątaja. Kraków 19882. Zob. także np. J. Leniek, Książka Pamiątkowa ku uczczeniu trzechsetnej rocznicy założenia Gimnazjum Św. Anny w Krakowie. Kraków 1888; J. Bąk, Semper in altum. Z Dziejów Szkół Nowodworskich. Kraków 1976; H. Sędziwy, J. Bąk, Historia Szkół Nowodworskich w latach 1945-1988. Kraków 1988.

${ }^{2}$ M. Ferenc, Collegium Nowodworskiego. Kraków 2012, s. 9-10.

${ }_{3}^{3}$ T. Graff, Szkoły Nowodworskie w Rzeczypospolitej Obojga Narodów - do reformy kołłąajowskiej w 1777 r. W: 420 lat Szkół Nowodworskich. Wydanie jubileuszowe I Liceum Ogólnokształcacego im. Bartłomieja Nowodworskiego w Krakowie. Pod red. T. Graffa, G. Urbanka. Kraków 2008, s. $7-38$.

${ }^{4}$ B. Przybyszewski, Piotr z Gorczyna. W: Polski słownik biograficzny [dalej: PSB]. T. 26. [Pod red. E. Rostworowskiego]. Wrocław 1981, s. 401-402; Z. Pietrzyk, Poczet rektorów Uniwersytetu Jagiellońskiego 1400-2000. Kraków 2000, s. 158; tenże, Wykształceni synowie chłopscy w Małopolsce 
privatae $^{5}$. Znając treść tego aktu, możemy pokusić się o ustalenie motywacji zebranych. Profesorowie pragnęli, aby studenci słuchali wykładów według stopnia własnego zaawansowania i dojrzałości, co pozwoliłoby uniknąć wielu nieporozumień, często zdarzających się dotychczas w tej materii. Inną motywacją było zmierzenie się z lenistwem, rozprzężeniem, lekceważeniem obowiązków i marnotrawieniem przez studentów pieniędzy swoich rodziców czy dobrodziejów. Wobec powyższego postanowiono zreformować dotychczasowy system edukacji poprzez powołanie prywatnych szkół.

„Postulowano mianowicie, aby uczeń przechodzący do wyższego poziomu nauczania, nie mógł już bez respektowania jakichkolwiek zasad i bez osądu jakiejś znamienitszej osobistości, dotyczącego jego postępów w nauce, wybierać dla siebie profesora, którego tylko by sobie życzył. Zamiast tego powinien zostać przydzielony przez egzaminatora, po odbytym egzaminie, z uwzględnieniem poczynionych przez niego postępów w nauce, do szkoły i do nauczyciela dlań najbardziej odpowiedniego. Ustalono również, że nauczyciele, którzy uczą w szkołach prywatnych, nie będą musieli przyjmować do swoich szkół każdego ucznia - bez możliwości dokonania wyboru - ale jedynie tych, którzy zostali uznani przez przełożonego szkoły za uczniów na to zasługujących". W dotychczasowej literaturze zwrócono uwagę, że przyczyn powstania nowych szkół mogło być kilka: zagrożenie szkolnictwem jezuickim, rozwój szkół różnowierczych, chęć dostosowania się do nowych trendów płynących z Zachodu, czy troska o poziom nauczania w murach wszechnicy krakowskiej’ W świetle przytoczonego dokumentu, tylko ten ostatni element został mocno zaakcentowany. Profesorowie nie napisali o zagrożeniu jezuickim czy różnowierczym. Nie powoływali się także na wzory zachodnie, ale bardzo konkretnie wskazali wady ówczesnego systemu i równie konkretnie postanowili temu zaradzić, przez powołanie szkół prywatnych, wraz z określeniem ścisłych zasad indywidualnego toku nauczania. Ponieważ uchwała ta nie została zrealizowana w trybie natychmiastowym, powrócono do niej w kwietniu $1588 \mathrm{roku}^{8}$ dzięki inicjatywie rektora

w epoce późnego Odrodzenia. Kraków 1993, s. 165-169; H. Barycz, Historia Szkół Nowodworskich..., s. 54 .

${ }^{5}$ M. Ferenc, Collegium Nowodworskiego..., s. 9 błędnie podaje datę 5 maja 1585 roku.

${ }^{6}$ Archiwum UJ, rkps 33, s. 363-364. Tekst polski uchwał z 1586 i 1588 roku podaję na podstawie T. Graff, Szkoły Nowodworskie..., s. 31-33 z niewielkimi korektami. Tekst łaciński zob. J. Leniek, Książka Pamiątkowa..., s. 1-3.

${ }^{7}$ H. Barycz, Historia Szkół Nowodworskich..., s. 24-25.

${ }^{8}$ Archiwum UJ, rkps 33, s. 378. 
Marcina Glicjusza z Pilzna9. Już w czerwcu, w trakcie rektoratu jego następcy Stanisława Pika Zawadzkiego ${ }^{10}$ na wniosek doktorów i nauczycieli współpracujących z uczelnią na walnym zgromadzeniu wszystkich wydziałów profesorowie podjęli nową uchwałę. Tutaj jako powód wymieniono dbałość o zdolności uczniów, które winny być stymulowane przez odpowiednie ćwiczenia. Poza tym zatroszczono się o jakość pracy samych profesorów. Wykładowcy uniwersyteccy nie powinni bowiem zaniedbywać swoich obowiązków poprzez praktykowane dotychczas prywatne dokształcanie krakowskich żaków. Poza tym postanowiono, ,aby wszystko, co podjęto i o czym zadecydowano do tej pory w kwestii powołania szkół, zostało sfinalizowane, a dzięki temu, by po zniesieniu kar cielesnych i uporaniu się z niedbalstwem uczniów, Uniwersytet zyskiwał na świetności”" ${ }^{\prime \prime}$. Profesorowie jednomyślnie postanowili powierzyć wykonanie tej uchwały rektorowi, zaznaczając przy okazji, iż nie wiedzą, dlaczego nie była ona do tej pory wykonana. Rektor niezwłocznie powołał zatem szkoły prywatne z siedzibą w Bursie Jerozolimskiej i szczegółowo zaplanował strukturę nowej instytucji. Po uroczystej mszy św. w kolegiacie św. Anny, w okazałej procesji orszak przeszedł do Collegium Maius. W trakcie tego pochodu niesiono przed rektorem insygnia jego władzy. Stanisław Pik Zawadzki osobiście przybył do Bursy, gdzie wygłosił piękną mowę, zachęcając studentów do poszanowania cnót, pielęgnowania i rozwijania wartościowych umiejętności, zachowania dobrych obyczajów oraz do umiłowania swoich nauczycieli. Następnie każda klasa otrzymała opiekunów: „Do Gramatyków wybrał szanowanych nauczycieli: Jana z Wiślicy, Jana Zaborowskiego i Adama Romera ze Stężycy, do Logików równie czcigodnego Rocha z Poznania i nauczyciela Andrzeja Szona z Głogowa, Retorów natomiast powierzył dostojnym nauczycielom Walentemu Fontanowi i Sebastianowi Petrycemu z Pilzna. Ich wybór uznał za najbardziej trafny ze względu na to, że dawali oni prywatne lekcje dużej liczbie uczniów i cieszyli się przy tym ich sympatią, a także z powodu ich oddania nauczaniu i wykształcenia każdego z ni$\mathrm{ch}^{12}$. Rzeczywiście, znając kariery owych nauczycieli, późniejszych wybitnych profesorów, luminarzy nauki i nierzadko nawet rektorów krakowskiej Almae Matris, widać, że Stanisław Pik Zawadzki dokonał właściwego wyboru. Sam

9 H. Barycz, Glicius Marcin. W: PSB. T. 8. [Pod red. K. Lepszego]. Kraków 1959, s. 48-50; Z. Pietrzyk, Poczet rektorów..., s. 152.

${ }^{10}$ Z. Pietrzyk, Poczet rektorów..., s. 154.

${ }^{11}$ T. Graff, Szkoły Nowodworskie..., s. 32.

${ }^{12}$ Tamże. 
rektor nieraz odwiedzał nowo utworzone klasy i wzywając opieki boskiej, robił wszystko „aby ugruntowana już opinia o głupocie i lekceważącym stosunku studentów do obowiązków uległa zmianie"13. Według tego samego dokumentu w pierwszym okresie działania udało się zgromadzić w klasach aż 530 uczniów, którzy przed rozpoczęciem edukacji musieli zaprzysiąc miłość i wierność wobec Akademii ${ }^{14}$. W świetle powyższych cytatów wydaje się, że głównym motywem powołania szkół prywatnych, była, jak już sygnalizowaliśmy, przede wszystkim głęboka troska władz uczelni i całego środowiska uniwersyteckiego o poziom nauczania w murach krakowskiej wszechnicy, jak również chęć wyrugowania dotychczasowych patologii, z pożytkiem dla młodzieży i samej kadry nauczającej. Oczywiście w tle podjętych decyzji z pewnością pojawiły się także obawy związane z ekspansją szkolnictwa jezuickiego, jak również szkół różnowierczych. Profesorowie nie dali jednak wyrazu tym obawom w oficjalnie zredagowanym tekście. Warto także dodać, że rektor Zawadzki doskonale znał z autopsji szkolnictwo funkcjonujące w Heidelbergu, ponadto nie był zbyt przychylnie nastawiony do działalności jezuitów, którzy założyli w Krakowie Sodalicję Mariańską, a ta $\mathrm{z}$ kolei skutecznie konkurowała $\mathrm{z}$ Akademią ${ }^{15}$. Spór z jezuitami toczył się przez kolejne dziesięciolecia i zakończył się zwycięstwem akademików, którzy w 1633 roku na sejmie warszawskim uzyskali wyrok nakazujący zamknąć w Krakowie szkoły jezuickie ${ }^{16}$.

Szkoły prywatne od początku borykały się z trudnościami. Jeszcze jesienią 1588 roku szalała w Krakowie zaraza. W roku następnym żacy przenieśli się do Bursy Nowej, a od 1643 roku zajęcia odbywały się w budynku Collegium Nowodworskiego ${ }^{17}$. Problemy finansowe były stałą bolączką słabo uposażonych nauczycieli, którzy w najniższych klasach musieli często walczyć z analfabetyzmem swoich podopiecznych. W 1603 roku rektor Mikołaj Dobrocieski przeprowadził w związku z tym reformę, która choćby częściowo miała zaradzić piętrzącym się kłopotom. Ustalono wtedy konkretne liczbę godzin zajęć w tygodniu - dla gramatyków 37, dialektyków 32, retoryków 22. Żaków miało uczyć 8 nauczycieli

13 Tamże.

${ }_{14}$ Por. H. Barycz, Historia Szkót Nowodworskich..., s. 57.

${ }_{15}$ B. Natoński, Jezuici a Uniwersytet Krakowski w XVI wieku. Kraków 2002; W. Urban, Akademia Krakowska $w$ dobie reformacji i wczesnej kontrreformacji (1549-1632). W: Dzieje Uniwersytetu Jagiellońskiego w latach 1364-1764. T. 1. Pod red. K. Lepszego. Kraków 1964, s. 279-280.

${ }^{16}$ S. Załęski, Jezuici w Polsce. T. 2: Praca nad spotęgowaniem ducha wiary i pobożności. 16o81648. Lwów 1901, s. 330.

${ }_{17}$ M. Ferenc, Collegium Nowodworskiego..., s. 10. 
doskonale posługujących się dwoma językami starożytnymi. Ich przełożonym (director scholarum privatarum) był każdorazowo jeden z profesorów Wydziału Filozoficznego, mianowany przez rektora na okres od jednego roku do trzech lat ${ }^{18}$. Niestety, pensje prowadzących zajęcia bezpośrednio zależały od opłat wnoszonych przez uczniów, a zatem niska frekwencja w poszczególnych klasach oznaczała skromne zarobki wykładowców. Nie zaradzono zatem najważniejszej bolączce - brakowi stałego źródła finansowania szkół prywatnych i dlatego w następnych dziesięcioleciach szczególnie istotne znaczenie dla przedłużenia funkcjonowania tej instytucji miały legaty możnych i profesorów Akademii Krakowskiej.

Pierwszym znaczącym darczyńcą był sam biskup krakowski Piotr Tylicki (zm. 1616), który ofiarował 10 tys. złp na nową katedrę profesorską. Jej posiadacz był odtąd zobowiązany do codziennych wykładów w Kolegium Większym (jedna godzina) i dwugodzinnych ćwiczeń w szkołach prywatnych. Uczniowie szkół prywatnych w trakcie tych zajęć mieli poprawiać swoje umiejętności z zakresu wymowy i stylu. Fundacja przynosiła 500 złp rocznie renty kapitałowej. Majątek wyderkaufowy oparto na dwóch miejscowościach: Sieborowicach i Pielgrzymowicach. Prawo patronatu posiadała kapituła krakowska, a prawo prezenty Uniwersytet. Podstawowym kryterium wyboru profesora były jego kwalifikacje. Przy tej okazji bp Tylicki ofiarował także 2 tys. złp na rzecz Bursy Ubogich (na bieżące potrzeby i remont budynku) ${ }^{19}$.

Kolejnym donatorem okazał się kawaler maltański Bartłomiej Nowodworski, herbu Nałęcz. Wywodził się ze szlachty pomorskiej, posiadającej majątki w okolicach Tucholi ${ }^{20}$. Bardziej szczegółowa kwerenda pozwala na ustalenie szczegółowych faktów w genealogii jego przodków. Nie wdając się w tym miejscu w szczegóły, z pewnością można w każdym razie skonstatować, że ród Nowodworskich posiadał znaczących antenatów w linii wielkopolskiej i mazowieckiej ${ }^{21}$. Sam Bartłomiej znany był ze swoich licznych przygód rycerskich. Służył

${ }^{18}$ H. Barycz, Historia Szkół Nowodworskich..., s. 72-73.

19 Archiwum UJ, akta papierowe 1436, 1476, 1478; Biblioteka Jagiellońska, rkps 41, k. 96v-97v, 117, rkps 226 IV, s. 82, 112, rkps 2501, s. 1091; J. Michalewicz, M. Michalewiczowa, Liber beneficiorum et benefactorum Universitatis Iagellonicae in saeculis XV-XVIII. T. 1. Kraków 1999, s. 277-278, nr $526-527$.

${ }^{20}$ H. Barycz, Nowodworski Bartłomiej. W: PSB. T. 23. [Pod red. E. Rostworowskiego]. Wrocław 1978 , s. $356-360$.

${ }^{21}$ Wśród znamienitych przodków Nowodworskiego należy wymienić sędziego warszawskiego Tomisława, poświadczonego w 1358 roku, jego syna Niemierzę z Nowego Dworu, który pełnił 
m.in. Zasławskim, Radziwiłłom i Batorym, walczył w wojnie o Inflanty z carem Iwanem Groźnym. Posłował także do Stambułu. Ta szybko zapowiadająca się kariera została gwałtownie zastopowana po tym, jak Nowodworski zabił w pojedynku szlachcica Biedrzyckiego i w związku z tym faktem musiał udać się na wygnanie. Brał udział w francuskiej wojnie trzech Henryków, a w 1599 roku znalazł się na Malcie. W roku 1605 złożył śluby zakonne, walczył z wyznawcami islamu, był nawet w Afryce. Przez cały ten czas utrzymywał kontakty z rodakami. Dzięki staraniom kawalera maltańskiego Piotra Kochanowskiego, który był notabene bratankiem słynnego poety, w 1607 roku Bartłomiej wrócił do Polski. Na dworze Zygmunta III Wazy pełnił funkcję kapitana osobistej straży królewskiej, tzw. harcerzy, brał udział w wyprawach na Moskwę, gdzie zasłynął z odwagi, m.in. próbując wysadzić bramy Smoleńska, Borysowa i Moskwy. $\mathrm{W}$ trakcie tych kampanii niejednokrotnie był ranny, co tylko dodawało mu prestiżu i sławy na salonach. Z biegiem lat krytycznie odnosił się do postawy króla, który według Nowodworskiego był „wesól, nic go nie dolega, choć jest o czym myśleć $[\ldots]$ choć Ojczyzna gore"22. Jedną z protektorek kawalera maltańskiego była sama Anna Wazówna, która osobiście pielęgnowała jego rany. Do końca chciał walczyć w obronie Ojczyzny, ponieważ jak twierdził „trzeba kawalerowi na polu umrzeć, a nie w łóżku" ${ }^{23}$. Pod koniec życia Nowodworski oddał się działalności dobroczynnej, ofiarował m.in. duże kwoty dominikanom warszawskim czy szpitalowi ubogich w Szydłowcu. Ten wielki miłośnik Bogurodzicy planował także szkolenie polskiej młodzieży w szeregach zakonu joannitów. Zmarł w 1625 roku w Warszawie, mając ok. 73 lat - wkrótce po otrzymaniu komendy maltańskiej w Poznaniu. Nad jego grobem wspaniałą mowę wygłosił Jakub Sobieski, który później wysłał swoich synów - Marka i Jana na naukę do Krakowa, właśnie do szkół nazwanych od nazwiska kawalera maltańskiego Nowodworskimi. Uniwersytet Krakowski uczcił go swoistym mauzoleum w kościele św. Anny. Mówiono o nim nawet jako o trzecim po Kazimierzu Wielkim i Władysławie

funkcję podstolego i kasztelana warszawskiego, oraz wnuka Dobrogosta z Nowego Dworu, kasztelana zakroczymskiego i warszawskiego, zm. w 1464 roku. Warto dodać, że bratem Niemierzy był arcybiskup gnieźnieński Dobrogost z Nowego Dworu, zm. 1401 roku. Zob. Nowy kodeks dyplomatyczny Mazowsza. Cz. 3: Dokumenty z lat 1356-1381. Wyd. I. Sułkowska-Kuraś, S. Kuraś. Warszawa 2000, $\mathrm{nr}$ 20, s. 25-26; $\mathrm{nr}$ 113, s. 126-127; nr 149, s. 158-159; J. Długosz, Vitae episcoporum Poloniae. W: Opera omnia. T. 1. Kraków 1887, s. 366; S. Trojanowski, Dobrogost. W: PSB. T. 5. [Pod red. W. Konopczyńskiego]. Kraków 1939, s. 245-246.

${ }^{22}$ H. Barycz, Nowodworski Bartłomiej..., s. 356-36o.

${ }^{23}$ Tamże. 
Jagielle fundatorze ${ }^{24}$. Ta pośmiertna laudacja dla Nowodworskiego zasługuje na uwagę tym bardziej, że w okresie życia kawalera maltańskiego Uniwersytet otrzymał ok. 350 innych fundacji25. Tymczasem profesorowie właśnie Bartłomiejowi oddali szczególne honory. Przyjrzyjmy się zatem jego donacjom, aby odpowiedzieć na pytanie, czy Nowodworskiemu rzeczywiście należały się szczególne słowa uznania.

Bartłomiej pierwszą pokaźną kwotę na Szkoły Nowodworskie ofiarował w 1612 roku. Było to 5 tys. złp z rentą kapitałową 300 złp. Majątek wyderkaufowy stanowiły miejscowości klucza pacanowskiego: Pacanów, Szczebrzuż, Słubice i Gacie, a także Wilamowice. Kolejne 3 tys. złp do tej samej fundacji Nowodworski ofiarował w $1617 \mathrm{roku}^{26}$. Tym samym renta kapitałowa została powiększona do 480 złp. Przy tej drugiej okazji 4 marca w dzień patrona młodzieży św. Kazimierza wygłosił piękną mowę, w której podkreślił, że nauka powinna harmonizować z miłością do Ojczyzny i narodowych tradycji. Z woli donatora uzyskane środki powinny być przeznaczone na uposażenie trzech profesorów i czterech biednych studentów katolików (trzech ze szlachty, jeden miał być plebejuszem) $z$ rodzinnych stron fundatora. Do obowiązków studentów pobierających borkarnę (rodzaj stypendium) należało m.in. ukończenie nauki w ramach trivium, uczestniczenie w lekcjach i dysputach publicznych w Akademii lub szkołach prywatnych, a także obrona minimum 5 tez w półroczu. Po każdym półroczu student musiał ponadto zdawać egzamin przed prowizorem borkarny i jednym magistrem. Wśród obowiązków religijnych zwraca uwagę konieczność odmawiania za duszę Nowodworskiego w każdą niedzielę 5 razy Ojcze nasz i Zdrowaś Mario, jak również raz na kwartał uczestniczenie w nabożeństwie do Ducha Świętego w kościele św. Anny i 5 mszach w kaplicy Bursy Jerozolimskiej. Gdyby żacy zaniechali wykonania tych obowiązków, mogli dostać upomnienie od prowizora, ale także stracić połowę stypendium, a w przypadku skrajnym, decyzją rektora i specjalnej rady - nawet całą borkarnę. Nowodworski w 1619 roku

${ }^{24}$ Tamże; tenże, Historia Szkót Nowodworskich..., s. 87-95. Na temat mowy pogrzebowej Jakuba Sobieskiego zob. M. Barłowska, Jakub Sobieski pamięci wielkiego kawalera Bartłomieja Nowodworskiego. Wraz z tekstem mowy Rzecz J. M. Pana Jakuba Sobieskiego [...] na pogrzebie sławnej pamięci Wielkiego Kawalera [...]. Szczecin 2006.

${ }^{25}$ J. Michalewicz, M. Michalewiczowa, Liber beneficiorum..., s. 133-305.

${ }^{26}$ Archiwum UJ, rkps 115, s. 49-50; rkps 151, s. 140-142; akta pap. 3882-389o, 3894-3899, 39093910, 3925, 5915, 5959; rkps 141, wklejka po k. 118; rkps A I 15, s. 294, 304; perg. 610-611; J. Michalewicz, M. Michalewiczowa, Liber beneficiorum ..., s. 260-262, nr 496; s. 284, nr 541; T. Graff, Szkoły Nowodworskie..., s. 16-17; H. Barycz, Historia Szkół Nowodworskich..., s. 95-105. 
ofiarował kolejne pieniądze. Było to 7 tys. złp. Z rocznym dochodem $420 \mathrm{złp}$, które były ulokowane w Pacanowie oraz we wsiach: Miechowice, Dziewięcioły i Nasiechowice. 60 złp przeznaczono przy tej okazji dla nauczycieli. Część kwoty fundator postanowił ofiarować na cele pobożne, a także 250 złp na druk publikacji naukowych. Miały one być starannie wydane na „papierze cudnym”, wszak Uniwersytet „jak żołnierz kopią, władnąć umie uczenie piórem”. Co ciekawe, jeden egzemplarz wydrukowanego dzieła miał być obowiązkowo wysłany do bibliotek w bursach i kolegiach. Przy okazji tej fundacji Bartłomiej przeznaczył 170 złp renty kapitałowej na uposażenie magistra sztuk wyzwolonych w szkole tucholskiej. W tym wypadku prawo prezenty otrzymał prowizor Szkół Nowodworskich. Nauczyciel w tej szkole, poza zwykłymi obowiązkami dydaktycznymi, miał za zadanie uczestnictwo wraz $\mathrm{z}$ uczniami w śpiewach podczas mszy św., odprawienie 5 mszy, a także zorganizowanie publicznych występów swoich podopiecznych (m.in. deklamacje, komedie) ${ }^{27}$.

Kolejnej fundacji na rzecz Akademii Nowodworski już nie zrealizował. Miało to być godne uposażenie Bursy Jerozolimskiej. Łączna suma, jaką ofiarował Bartłomiej Nowodworski, opiewała zatem ostatecznie na kwotę 15 tys. złp. Czy była to darowizna najwyższa i najbardziej znacząca dla szkół zwanych później Nowodworskimi? Biorąc pod uwagę spadek wartości pieniądza i kryzys gospodarczy, widoczny zwłaszcza w drugiej połowie XVII wieku, skupmy się w pierwszej kolejności na fundacjach, które licząc od początków istnienia szkół prywatnych, zamknęły się w pierwszej połowie tego stulecia. Taki był także punkt odniesienia włodarzy Akademii Krakowskiej, którzy, o czym była mowa wyżej, nie szczędzili kawalerowi maltańskiemu dowodów wdzięczności. W następnej kolejności przeanalizujemy także pozostałe fundacje z okresu staropolskiego.

Obok darowizny Nowodworskiego dla szkół prywatnych równie ważną, jeśli nie ważniejszą, była donacja Gabriela Prewancjusza Władysławskiego opiewająca niemal na 50 tys. złp.

Gabriel Prewancjusz Władysławski (ok. 1570-1631), wychowanek jezuicki i bakałarz Akademii Krakowskiej, był plebejem, który szybko zrobił karierę

${ }_{27}$ Archiwum UJ, perg. 613-615; akta pap. 1317, 1427-1430, 1599, 5915; rkps 141, wklejka między k. 118-119; rkps A I 13, s. 168, 295; J. Michalewicz, M. Michalewiczowa, Liber beneficiorum..., s. 290-291, nr 551; T. Graff, Szkoły Nowodworskie..., s. 16-17; H. Barycz, Historia Szkół Nowodworskich..., s. 95-105. Zob. też: Dwie fundacje Jego Mci P. Bartłomieia Nowodworskiego w sławney Akad Krakowskiey, y w Tucholskiey szkole. Z lácińskiego ná Polskie przettumáczone przez M. Wawrzyńca Smieszkowica. Oprac. J. Andrzejewski. Tuchola 1987. 
i uzyskał szlachectwo oraz zgromadził znaczny majątek dzięki służbie na dworze Zygmunta III Wazy. Pełnił urząd opiekuna szkoły paziów, sekretarza królewskiego i przede wszystkim wychowawcy królewiczów: Władysława, Jana Kazimierza, Jana Olbrachta, Karola Ferdynanda oraz Aleksandra i królewny Anny Marii. Chlubił się także tytułem doktora teologii, który rzekomo zdobył we Włoszech. Posiadał ponadto liczne prebendy kościelne. Stale wspierał Akademię, zwłaszcza w jej sporze z jezuitami. W jego posiadłości Bartłomiej Nowodworski wraz z bratankiem Jerzym oprawiali antyjezuicki pamflet, który następnie rozrzucono na sejmie ${ }^{28}$. 31 sierpnia 1630 roku Władysławski dokonał zapisu na rzecz Akademii (faktycznie były to dwie fundacje: 30 tys. oraz 20 tys. złp $)^{29}$. Brakującą kwotę 20 tys. złp uzyskano dopiero w 1633 roku na mocy zatwierdzenia samego Władysława IV dzięki wysiłkowi Jana Raciborskiego, po niemałych zresztą perturbacjach. Faktycznie na rzecz szkół prywatnych przeznaczono ostatecznie 47,4 tys. złp, z rentą opiewającą na sumę 3008 złp rocznie. Majątek wyderkaufowy stanowiła miejscowość Izbica, własność kolegi ze studiów Prewancjusza - kasztelana lędzkiego Jana Łowickiego ${ }^{30}$. Dzięki tej kwocie udało się wybudować nowy gmach szkół prywatnych przy wsparciu prowizora Adama z Opatowa, a także dzięki dotacjom rektora Jakuba Najmanowicza - 1 tys. złp i samego króla Władysława IV - 2,5 tys. złp ${ }^{31}$. Początkowo zakładano utworzenie 8 katedr, a wzorem miał być model francuski - College Royal - instytucja założona przez Franciszka I w 1530 roku. Ostatecznie utworzono 7 katedr, które miały być obsadzane w drodze konkursów przez wybitnych specjalistów, wykładających swój przedmiot ogólnie, mniej drobiazgowo. Żacy powinni natomiast zaliczać dany kurs w ściśle określonych terminach. Wykładowcy niekoniecznie musieli pochodzić z grona profesorskiego krakowskiego Uniwersytetu. W zamierzeniu fundatora w szkołach powinno się nauczać: architektury wojskowej i geometrii, prawa kanonicznego i cywilnego, historii i chronologii, kazuistyki teologicznej, geografii oraz propedeutyki filozo-

${ }^{28}$ Ks. Jana Wielewickiego T.J. Dziennik spraw domu zakonnego OO. Jezuitów u św. Barbary $w$ Krakowie od r. 1620 do r. 1629 włacznie. Wyd. W. Chotkowski. W: Scriptores Rerum Polonicarum. T. 17. Kraków 1889, s. 129-139, 245-246; M. Ferenc, Collegium Nowodworskiego..., s. 11-12; T. Graff, Szkoły Nowodworskie..., s. 18; H. Barycz, Historia Szkół Nowodworskich..., s. 134 n.

${ }_{29}$ Archiwum UJ, rkps 206, s. 250; rkps 163, ss. 7; Akta pap. 5914-5915, 5950, 5954, 5959, 10072, 12343, 12622-12633, 14125-14126, 14130; J. Michalewicz, M. Michalewiczowa, Liber beneficiorum..., s.320-322, nr 6oo-6o1.

${ }^{30}$ M. Ferenc, Collegium Nowodworskiego..., s. 11-12.

${ }^{31}$ Tamże. 
fii $^{32}$.Założenia te spotkały się z oporem konserwatystów akademickich, niemniej jednak główna część testamentu Władysławskiego została zrealizowana.

Fundacja Gabriela Prewancjusza Władysławskiego ponad trzykrotnie przewyższyła kwotę wydatkowaną przez kawalera maltańskiego Nowodworskiego na rzecz szkół prywatnych. Bez ryzyka można stwierdzić, że z pewnością przyczyniła się nie tylko do powstania nowych katedr, ale przede wszystkim do wybudowania barokowego gmachu szkół, który przez wiele lat nosił miano Collegium Władysławowsko-Nowodworskiego. Z czasem zapomniano jednak o Władysławskim i tym samym Bartłomiej Nowodworski, nie do końca zgodnie z prawdą historyczną, zapisał się w pamięci następnych pokoleń jako najważniejszy fundator i benefaktor szkół prywatnych.

Oprócz wymienionych wyżej fundacji w okresie staropolskim Szkoły Nowodworskie miały także innych benefaktorów, choć żaden z nich, z wyjątkiem może Stanisława Garwaskiego, nie mógł równać się hojnością z bp. Piotrem Tylickim, Bartłomiejem Nowodworskim czy Gabrielem Prewancjuszem Władysławskim. Warto jednak ukazać te fundacje w zestawieniu z wyżej wymienionymi w kolejności chronologicznej:

Tabela 1. Fundacje na rzecz Szkół Nowodworskich XVII-XVIII w.

\begin{tabular}{|c|l|l|l|}
\hline Lp. & $\begin{array}{l}\text { Data } \\
\text { fundacji }\end{array}$ & Fundator & $\begin{array}{l}\text { Darowizna, kwota } \\
\text { bądź przedmiot fundacji }\end{array}$ \\
\hline 1. & 1612 & kawaler maltański Bartłomiej Nowodworski & $5000^{\mathrm{a}}$ \\
\hline 2. & 1615 & biskup krakowski Piotr Tylicki & $10000^{\mathrm{b}}$ \\
\hline 3. & 1617 & kawaler maltański Bartłomiej Nowodworski & $3000^{\mathrm{c}}$ \\
\hline 4. & 1619 & kawaler maltański Bartłomiej Nowodworski & $7000^{\mathrm{d}}$ \\
\hline 5. & ok. 1619 & rektor Akademii Krakowskiej Jakub Janidło & $1000^{\mathrm{e}}$ \\
\hline 6. & $1629-1639$ & kanonik krakowski Andrzej Tarło ze Szczekarzewic & $5000^{\mathrm{f}}$ \\
\hline 7. & 1630 & dziekan warszawski Jan Raciborski & $3333^{\mathrm{g}}$ \\
\hline 8. & 1630 & Gabriel Prewancjusz Władysławski & $30000^{\mathrm{h}}$ \\
\hline 9. & $1630-1633$ & Gabriel Prewancjusz Władysławski & $20000^{\mathrm{i}}$ \\
\hline 10. & 1633 & Maciej Kwaśniowicz & drobna kwota \\
\hline 11. & $1635-1637$ & dziekan płocki i kanonik krakowski Stanisław Garwaski & $\begin{array}{l}\text { bonkarna i uposażenie } \\
\text { kzlacheckiej krwik }\end{array}$ \\
\hline
\end{tabular}

${ }^{32}$ Szczegóły fundacji zob. J. Michalewicz, M. Michalewiczowa, Liber beneficiorum..., s. 320322, $\mathrm{nr} 600-601$. 


\begin{tabular}{|c|c|c|c|}
\hline 12. & 1637 & dziekan płocki i kanonik krakowski Stanisław Garwaski & $10000^{1}$ \\
\hline 13. & 1638 & rektor Akademii Krakowskiej Jakub Najmanowicz & $1000^{\mathrm{m}}$ \\
\hline 14. & 1638 & król Władysław IV & $2500^{\mathrm{n}}$ \\
\hline 15. & 1639 & doktor obojga praw Jan Baranowski & $1500^{\circ}$ \\
\hline 16. & 1642 & pleban Woli Radziszowskiej Jan Fugaszowic & $3600^{\mathrm{P}}$ \\
\hline 17. & 1646 & doktor teologii i pleban w Kętach Grzegorz Jan Zdziewojski & $500^{\mathrm{q}}$ \\
\hline 18. & 1646 & biskup warmiński Szymon Rudnicki (zm. 1621) & $1000^{\mathrm{r}}$ \\
\hline 19. & 1647 & ksiądz Łukasz Hajkowski & dom $\mathrm{z}$ ogrodem ${ }^{\mathrm{s}}$ \\
\hline 20. & 1648 & doktor teologii Jakub Witeliusz & $200^{t}$ \\
\hline 21. & 1648 & prowizor szkół prywatnych Adam Draski & $100^{\mathrm{u}}$ \\
\hline 22. & 1648 & doktor teologii i kanonik krakowski Andrzej Haszkowski & $1000^{\mathrm{v}}$ \\
\hline 23. & 1664 & doktor medycyny i obojga praw Jan Toński & $6000^{\mathrm{w}}$ \\
\hline 24. & 1692 & $\begin{array}{l}\text { dziekan kościoła św. Michała na Wawelu } \\
\text { Jan Strączkowski; } 1709 \text { r. przekazanie fundacji Szkołom } \\
\text { Nowodworskim }\end{array}$ & $4000^{x}$ \\
\hline 25. & 1720 & rektor Akademii Krakowskiej Marcin Ośliński & $1000^{y}$ \\
\hline 26. & 1728 & dziekan kurzelowski Łukasz Łaniewski & $1000^{\mathrm{z}}$ \\
\hline 27. & 1739 & doktor teologii Marcin Waleszyński & $500^{\text {aa }}$ \\
\hline 28. & 1742 & fundator nieznany & $100^{\mathrm{bb}}$ \\
\hline 29. & 1745 & sekretarz królewski Tomasz Szreniawski & ok. poł. z $12000^{\mathrm{cc}}$ \\
\hline
\end{tabular}

a Zob. przyp. 24.

b Zob. przyp. 19.

c Zob. przyp. 24.

d Zob. przyp. 25.

e Archiwum UJ, rkps 36, s. 204.

f Archiwum UJ, rkps 111, s. 50-52; rkps 115, s. 84; akta pap. 3969-3971, 5959; J. Michalewicz, M. Michalewiczowa, Liber beneficiorum..., s. 314-315, nr 592.

g Archiwum UJ, rkps 115, s. 63-63; rkps 144a; J. Michalewicz, M. Michalewiczowa, Liber beneficiorum..., s. 317, nr 596.

h Zob. przyp. 27.

i Zob. tamże.

j $\quad$ Archiwum UJ, rkps 36, s. 301.

k Bursa Garvasciana. Abo Fundacya na trzydziestu studentów szlacheckiej krwie. Kraków 1637; H. Barycz, Historia Szkół Nowodworskich..., s. 185-189.

l Archiwum UJ, akta pap. 3177-3194, 3207, 3195-3201, 5959; J. Michalewicz, M. Michalewiczowa, Liber beneficiorum..., s. 347, nr 644.

m H. Barycz, Historia Szkół Nowodworskich..., s. 180.

n Tamże. 
o Archiwum UJ, rkps 117; rkps 246, s. 98-103; akta pap. 3537-3538, 3547, 5946; J. Michalewicz, M. Michalewiczowa, Liber beneficiorum..., s. 369, nr 677.

p Archiwum UJ, rkps 115, s. 73; rkps 132, ss.19; rkps 135; akta pap. 4250-4252; J. Michalewicz, M. Michalewiczowa, Liber beneficiorum..., s. 393-394, nr 711-713.

q Archiwum UJ, rkps 19, s. 224, 240; rkps 35, s. 702-713; rkps 111, s. 21-26; rkps 115, s. 97; rkps 185, s. 2; rkps A I, s. 291; rkps A I 15, s. 291; akta pap. 3848-3864, 3868-3871, 5959; J. Michalewicz, M. Michalewiczowa, Liber beneficiorum..., s. 412-413, nr 747; H. Barycz, Historia Szkół Nowodworskich..., s. 189-191.

r Archiwum UJ, rkps 37, s. 344; rkps 111, s. 613; H. Barycz, Historia Szkół Nowodworskich..., s. 189.

s Archiwum UJ, rkps 4, s. 211; Biblioteka Jagiellońska, rkps 226 IV 447; H. Barycz, Historia Szkół Nowodworskich..., s. 244.

t Archiwum UJ, rkps 36, s. 50; akta pap. 5369, 5959; J. Michalewicz, M. Michalewiczowa, Liber beneficiorum..., s. 432, nr 779 .

u H. Barycz, Historia Szkół Nowodworskich..., s. 244.

v Archiwum UJ, akta pap. fasc. 507, nr 1570-1594; J. Michalewicz, M. Michalewiczowa, Liber beneficiorum..., s. 434-435, nr 782.

w Archiwum UJ, akta pap. 2910-2916, 5156, 5951-5952, 5959; J. Michalewicz, M. Michalewiczowa, Liber beneficiorum..., s. 485, nr 861.

x Archiwum UJ, rkps 48, s. 316-323; akta pap. 1550-1551, 1554-1557, 5959; J. Michalewicz, M. Michalewiczowa, Liber beneficiorum..., s. 568, nr 1011.

y H. Barycz, Historia Szkół Nowodworskich..., s. 244.

z Archiwum UJ, rkps A I 15, s. 227; rkps 141, wklejka między k. 118 a 119; akta pap. 3450-3452, 5951, 5959; J. Michalewicz, M. Michalewiczowa, Liber beneficiorum..., s. 629, nr 1139.

aa Archiwum UJ, rkps 1, s. 73; H. Barycz, Historia Szkół Nowodworskich..., s. 244.

bb Archiwum UJ, akta pap. 5959; J. Michalewicz, M. Michalewiczowa, Liber beneficiorum..., s. 647, nr 1183 .

cc Archiwum UJ, rkps 159, ss. 66; akta pap. 5994; J. Michalewicz, M. Michalewiczowa, Liber beneficiorum..., s. 654-655.

Zestawienie to, obejmujące 29 fundacji uczynionych przez 25 fundatorów, choć zapewne niepełne, pozwala jednak na wysunięcie konkretnych wniosków. Z powyższego wykazu wynika bowiem, że większość znanych fundacji na rzecz Szkół Nowodworskich miała miejsce jeszcze w XVII wieku, ze szczególną kumulacją w latach panowania dwóch pierwszych Wazów, co w dużej mierze pokrywało się z okresem ich największego rozkwitu. Na 29 analizowanych fundacji aż 22 pochodziły z pierwszej połowy XVII wieku. Co znamienne, kryzys państwa, widoczny na wielu polach, szczególnie w okresie powstania Chmielnickiego i potopu szwedzkiego, oraz w następnych dziesięcioleciach, dotknął także Szkoły Nowodworskie, co zaowocowało spadkiem dynamiki fundacji w drugiej połowie XVII wieku i w czasach saskich - w sumie tylko 7 donacji w tym okresie. Doskonale proces ten ilustruje wykres dynamiki fundacji w poszczególnych dziesięcioleciach (zob. ryc.1. Dynamika fundacji na rzecz Szkót Nowodworskich $w$ XVII-XVIII w.). 
Ryc. 1.

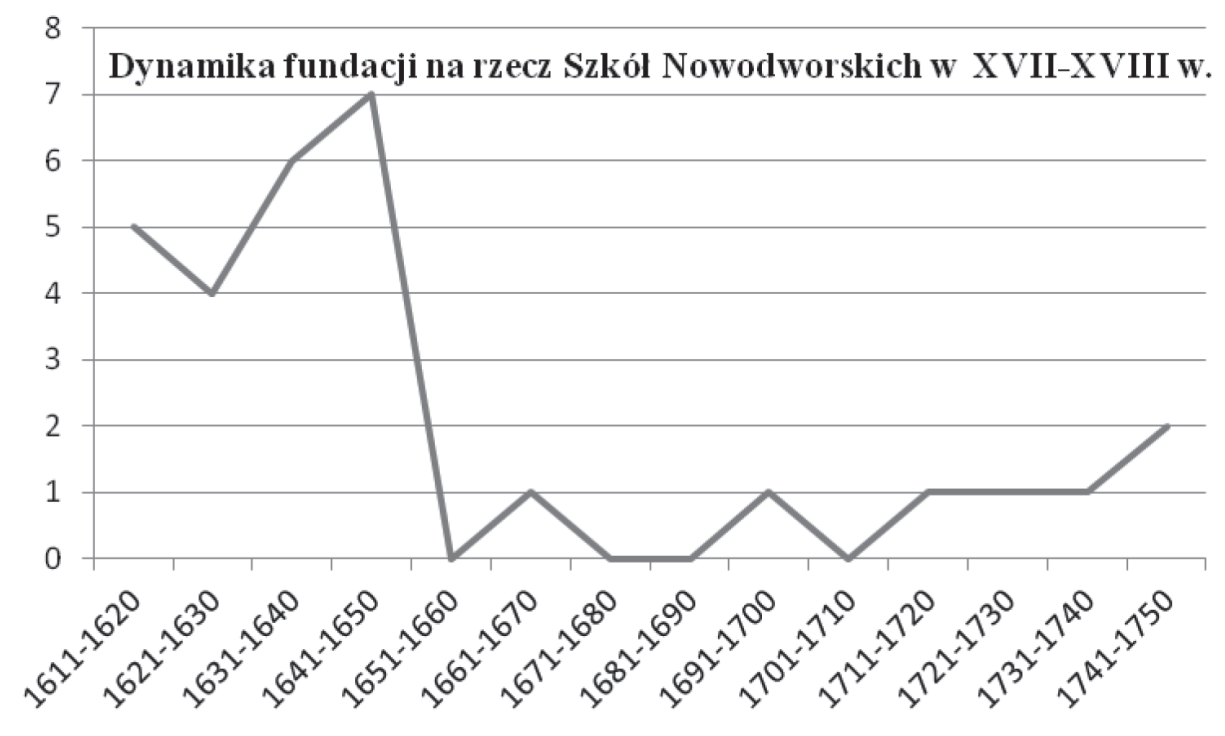

Fundatorami byli zazwyczaj profesorowie uniwersyteccy, ludzie Kościoła z biskupami na czele (Tylicki, Rudnicki), ale także świeccy, jak Bartłomiej Nowodworski czy sam król Władysław IV Waza. Spadek liczby fundacji w drugiej połowie wieku XVII i w XVIII wieku przyczynił się do pogorszenia sytuacji materialnej profesorów szkół prywatnych i samej placówki. Obok najbardziej znanych fundacji należy podkreślić znaczenie darowizny Andrzeja Tarły, który oprócz ufundowania stypendium dla sześciu studentów, uposażył także pięciu nauczycieli szkół prywatnych (po 40 złp rocznie), ci zaś w zamian musieli śpiewać wraz z uczniami litanię loretańską i kolektę do św. Józefa (lp. 6) Z kolei Jan Raciborski ufundował borkarnę dla żaków pochodzących z ziemi warszawskiej i czerskiej, zarówno dla szlachciców (2/3 renty), jak i plebejów (1/3). W zamian stypendyści powinni byli odmawiać w niedziele i święta litanię do NMP i trzy razy Ojcze nasz. Ponadto raz na kwartał za duszę fundatora psalm Miserere. Czwartą część renty ogólnej Raciborski przeznaczył natomiast na uposażenie szpitala w Piasecznie (lp. 7). Zwraca uwagę także fundacja z 1646 roku doktora teologii i plebana w Kętach Grzegorza Jana Zdziewojskiego, który wyznaczył część kwoty (25 złp rocznie) na borkarnę dla nowodworczyków na zakup papieru, ich uposażenie oraz ustanowił fundusz dla kapelna na msze i dla prowizora szkół (lp. 17). Do znaczących należała także z pewnością fundacja medyka 
i prawnika Jana Tońskiego z roku 1664, która opierając się na kwocie 6 tys. złp i rocznej rencie kapitałowej 360 złp, była przeznaczona na uposażenie profesorów Kolegium - po 15 złp na semestr (lp. 23). O płace wykładowców nowodworskich zadbał także w 1692 roku dziekan kościoła św. Michała na Wawelu Jan Strączkowski, ofiarowując kwotę 4 tys. złp. Fundacja ta, wchodząc w życie w 1709 roku, dawała każdemu profesorowi 30 złp rocznie (lp. 24). Podobną darowiznę ofiarował dziekan kurzelowski Łukasz Łaniewski w 1728 roku. Jego fundacja nakładała na profesorów i studentów obowiązek odśpiewania za duszę benefaktora w każdą sobotę Salve Regina. Renta kapitałowa wynosiła 50 złp rocznie i miała być przeznaczona do podziału między profesorów (lp. 26). Ostatnią fundacją na rzecz Szkół Nowodworskich była dotacja sekretarza królewskiego Tomasza Szreniawskiego z 1745 roku. Kapitał fundacyjny wynosił 12 tys. złp, z roczną rentą $600 \mathrm{złp}$. Jednak tylko część tej kwoty przeznaczono na rzecz studentów Collegium Nowodworskiego. Stypendium miało pobierać czterech żaków, krewnych fundatora lub pochodzących z Nowego Sącza, albo 12-20 studentów szkół prywatnych. Student miał otrzymywać 1 złp na tydzień. Stypendium to mógł pobierać przez trzy lata. Fundator zapewniał stypendystom także całoroczne posiłki. W zamian w niedziele i święta miano odmawiać litanię do Jezusa i psalm de profundis. Pozostałe części tej fundacji zostały rozdzielone na Bursę Filozofów, Kolegium Większe, kolonię akademicką w Nowym Sączu i inne pomniejsze legaty (lp. 29). Według Henryka Barycza ostatnią fundacją na rzecz Szkół Nowodworskich był jednak nie zapis Szreniawskiego z 1745 roku, ale profesora teologii Macieja Fedorowicza z roku 1728 „w kwocie 1000 złp, przeznaczony dla profesorów za odśpiewanie Salve Regina co sobotę za duszę ofiarodawcy”"33. Powyższe ustalenia podważają jednak tę tezę, tym bardziej że Barycz pomylił Federowicza z Łukaszem Łaniewskim, który dokonał wtedy zapisu przytoczonej treści. Sam zaś Federowicz rzeczywiście dokonał fundacji w tym samym roku, na kwotę 5 tys. złp, ale na rzecz kolegiaty św. Anny ${ }^{34}$. Barycz nie znał także fundacji anonimowego benefaktora $\mathrm{z} 1742$ roku (lp. 28).

Osobną pulę datków stanowiły darowizny na oratorium akademickie, które mieściło się od 1643 roku na pierwszym piętrze w Nowodworscianum. Wśród fundatorów należy tutaj wymienić m.in. księdza Łukasza Hajkowskiego (lp. 19),

${ }^{33}$ H. Barycz, Historia Szkół Nowodworskich..., s. 225; por. T. Graff, Szkoły Nowodworskie..., S. $20-21$.

${ }^{34}$ Archiwum UJ, rkps 204, rkps 206, s. 14, 21-22; akta pap. 3592- 3604; J. Michalewicz, M. Michalewiczowa, Liber beneficiorum..., s. 630-631, $\mathrm{nr} 1141$. 
doktora teologii i kanonika krakowskiego Andrzeja Haszkowskiego, który ufundował także borkarnę dla dwóch studentów (lp. 22); prowizorów szkół Jakuba Witelisza (lp. 20) i Adama Draskiego (lp. 21), a taże rektora Akademii Krakowskiej Marcina Oślińskiego (lp. 25) i Marcina Waleszyńskiego (lp. 27). Jednak bezsprzecznie największą darowiznę na rzecz oratorium przeznaczył w 1637 roku dziekan płocki i kanonik krakowski Stanisław Garwaski. Wynosiła ona aż 10 tys. złp. Renta miała być rozdzielona między kapelanów, spowiedników, ekonoma, na reperację paramentów kościelnych oraz na zakup wosku i wina (lp. 12). Dwa lata wcześniej Garwaski ufundował borkarnę dla swoich krewnych i innych młodzieńców pochodzenia szlacheckiego z woj. płockiego, którzy mieli studiować nauki prawne. Siedzibą konwiktu została Bursa Jurystów przy ul. Grodzkiej. Stypendyści korzystali ze stołówki, mając do dyspozycji chleb i piwo bez ograniczeń oraz dwa obfite posiłki w ciągu dnia, z wyjątkiem dni postnych, kiedy przysługiwała im polewka, ryba i jarzyny (lp. 11).

Warto także dodać, że szkoły otrzymywały także cenne dary materialne, jak to miało miejsce np. w roku 1618, kiedy to pisarz i sekretarz królewski Jerzy Nowodworski ofiarował 30 książek dla stypendystów fundacji Bartłomieja Nowodworskiego ${ }^{35}$. Z kolei Jakub Witeliusz, obok fundacji wieczystej 200 złp przeznaczonej na zakup opału dla wykładowców, przekazał dla studentów pokaźny księgozbiór humanistyczny. Natomiast historię świata Sabelica i dwa greckie dzieła ofiarował Adam Draski. Dary profesorskie (np. Śmieszkowica) pomogły zaś w wyposażeniu wnętrza kaplicy nowodworskiej ${ }^{36}$.

\section{Podsumowanie}

Szczodrość benefaktorów pozwoliła na sprawne funkcjonowanie szkół prywatnych w pierwszym stuleciu jej istnienia, natomiast wysychające źródło donacji w następnym okresie niejednokrotnie stawiało byt tej instytucji pod znakiem zapytania. Mimo licznych kryzysów Szkoły Nowodworskie dotrwały jednak do reformy kołłątajowskiej w 1777 roku, która przekształciła je według

${ }^{35}$ H. Barycz, Nowodworski Jerzy. W: PSB, t. 23, s. 366-367. Towarzysz chorągwi husarskiej Jerzy zmarł ok. 1639 roku. Był synem sędziego tucholskiego Grzegorza.

${ }^{36}$ Tenże, Historia Szkół Nowodworskich..., s. 157-159, 246. 
założeń KEN w Szkołę Przygłówną ${ }^{37}$. W okresie późniejszym instytucja ta była znana jako Gimnazjum św. Anny ${ }^{38}$, obecnie w jej murach mieści się I LO im. Bartłomieja Nowodworskiego. Oprócz Jana i Marka Sobieskich w kolejnych dziesięcioleciach i stuleciach do Szkół Nowodworskich uczęszczali luminarze polskiej nauki, kultury i polityki. Obok Uniwersytetu Jagiellońskiego placówka ta stanowi jedną z nielicznych instytucji szkolnych w Polsce, której metryka liczy sobie kilkaset lat. Swój byt Szkoły Nowodworskie nie zawdzięczają jednak tylko najbardziej znanemu fundatorowi Bartłomiejowi Nowodworskiemu, ale mądrości profesorów-założycieli w latach 1586-1588, a także całej plejadzie bardziej i mniej znanych dobrodziejów, którzy przez dziesięciolecia wspierali ich działanie. Z pewnością szczególnie należy podkreślić wagę daru Gabriela Prewancjusza Władysławskiego, dzięki któremu zbudowano istniejący do dzisiaj budynek Collegium. Obiekt ten znany jest dziś głównie z imienia kawalera maltańskiego Bartłomieja Nowodworskiego lub jako budynek Collegium Medicum Uniwersytetu Jagiellońskiego. Tym samym można skonstatować, że właściwy fundator tego barokowego gmachu popadł w zapomnienie ${ }^{39}$.

37 Tamże, s. 251-252, 265-266; M. Chamcówna, Epoka wielkiej reformy. W: Dzieje Uniwersytetu Jagiellońskiegow latach 1765-1850. T. 2, cz. 1. Pod red. K. Opałka. Kraków 1965, s. 7-17; J. Leniek, Książka Pamiątkowa..., s. 81-110; T. Graff, Szkoły Nowodworskie..., s. 29-30.

${ }^{38}$ Zob. interesujący artykuł P. Bilińskiego, Studium z dziejów Liceum i Gimnazjum św. Anny w Krakowie, „Kwartalnik Historii Nauki i Techniki” R. 54: 2009, nr 1, s. 35-77.

${ }^{39} \mathrm{O}$ znaczeniu fundacji Gabriela i króla Władysława IV informuje co prawda tablica z 1777 roku umieszczona nad portalem budynku z herbem Wazów. Jednak jest ona zniszczona i słabo czytelna, także z powodu wysokości. Współcześnie natomiast umieszczono na budynku dobrze czytelną tabliczkę z bałamutną informacją, iż gmach powstał w wyniku fundacji Bartłomieja Nowodworskiego. 


\section{Streszczenie}

\section{Wokół staropolskich fundacji i benefaktorów Szkół Nowodworskich w Krakowie}

Szkoły Nowodworskie, których kontynuatorką jest dzisiejsze I LO im. B. Nowodworskiego, mają kilkusetletnią historię. Idea założenia szkół narodziła się w gronie profesorów Akademii Krakowskiej w 1586 roku, ale do właściwego otwarcia placówki doszło 2 lata później, dzięki inicjatywie profesora Stanisława Pika Zawadzkiego. W pierwszych dziesięcioleciach istnienia instytucja musiała zmierzyć się z licznymi trudnościami, takimi jak epidemie czy też naciski konserwatywnych profesorów, chcących zamknąć szkoły. W tych trudnych początkach szczególnie pomógł placówce biskup krakowski Piotr Tylicki. Jako benefaktor przeznaczył szkołom 10 tys. zł. Kolejnym ważnym dobrodziejem był kawaler maltański Bartłomiej Nowodworski, który w 3 fundacjach w latach 1612, 1617 i 1619 ofiarował w sumie 15 tys. zł. Darowizna ta pomogła instytucji przetrwać. Szkoły Nowodworskie miały w dalszych dziesięcioleciach wielu benefaktorów. Najważniejszym z nich był Gabriel Prewancjusz Władysławski, który darował 50 tys. zł. Dzięki temu, przy wydatnej pomocy króla Władysława IV Wazy, mógł powstać nowy budynek szkół zbudowany w 1643 roku. Dynamika fundacji w następnych dziesięcioleciach znacznie jednak spadła, co było efektem postępującego zubożenia kraju. Ostatnim odnotowanym darczyńcą był w 1745 roku sekretarz królewski Tomasz Szreniawski.

\section{Summary}

\section{The foundations and the benefactors of Nowodworski Schools in Cracow}

Nowodworski Schools, whose current institutionalized continuator is Bartłomiej Nowodworski High School, have a legacy of a long history. The idea to found private schools was initially brought forward by the authorities and professors of the Cracovian University in 1586 . The project was finally launched in 1588 mainly due to energetic steps taken by the subsequent chancellor of the Cracovian University doctor of medicine - Stanisław Pik Zawadzki. Over the first decades of its existence the schools faced numerous hardship. The institution was underfunded and both professors and students were exposed to epidemics so frequent in those times, such as for instance the plague 
in September 1588. Some conservative professors of the University also called for closing the academic colonies. Despite all the predicaments, the institution managed to survive. The most important benefactor for private schools in those difficult years was a Cracovian bishop Piotr Tylicki (in office: 1607-1616), who with the consent of the local chapter, donated PLN 10 ooo to fund a separate professor department where the professors were obliged to give a one hour daily lecture in The Upper College as well as 2 hour classes in pronunciation and stylistic in private schools. The situation, however, did not improved significantly. In those times of crisis of private schooling there appeared the foundations of the Knight of the Maltese Order - Barłomiej Nowodworski. Nowodworski was a benefactor for numerous institutions, however, his most famous charity was his foundations for Nowodworski Schools. He donated PLN 8000 in 1612, 1617 and PLN 7000 in 1619 making it possible for those private schools to survive the difficult times. Nowodworski Schools had many benefactors, however, besides the foundation of B. Nowodworski the most prominent benefactors were Gabriel Prewancjusz Władysławski. He donated PLN 50 ooo. Thanks to his efforts and with the contribution from the King new premises for the private schools were built in 1643 . 